\title{
Budidaya Rumput Laut Gelidium sp. menggunakan Kantong pada Metode Long Line dan Lepas Dasar
}

\section{Cultivation of Seaweed Gelidium sp. used the Pouch on the Long Line and Bottom- Off Methods}

\author{
Muslimin Muslimin ${ }^{1}$ \& Nelly Hidayanti Sarira*2 \\ 'Loka Riset Budidaya Rumput Laut Gorontalo, Gorontalo, Indonesia \\ ¿Loka Perekayasaan Teknologi Kelautan Wakatobi, Sulawesi Tenggara, Indonesia \\ *Corresponding author, email: nellyhidayantisarira@gmail.com
}

Submitted 30 January 2020 Revised 10 February 2020 Accepted 30 November 2020

\begin{abstract}
Abstrak Tujuan penelitian ini adalah untuk mengetahui pertumbuhan rumput laut Gelidium sp. yang dibudidayakan dengan kantong pada dua metode berbeda yaitu long line dan lepas dasar.Rancangan percobaan yang digunakan yaitu Rancangan Acak Lengkap (RAL) yang terdiri dari dua metode (long line dan lepas dasar) dan dua perlakuan yaitu : 1. Uji coba bobot awal rumput laut (bobot bibit $10 \mathrm{~g}, 20 \mathrm{~g}, 30 \mathrm{~g}, 40 \mathrm{~g}, 50 \mathrm{~g}, 75 \mathrm{~g}, 100 \mathrm{~g}$, dan $125 \mathrm{~g}$ ) dan 2. Uji coba jarak tanam antar rumpun bibit $(10 \mathrm{~cm}, 15 \mathrm{~cm}, 20 \mathrm{~cm}$, dan $25 \mathrm{~cm})$. Masing-masing perlakuan diulang tiga kali.Hasil penelitian menunjukkan bahwa pertumbuhan Gelidium sp.menggunakan metode long line dan lepas dasarberpengaruh nyata terhadap bobot awal dan jarak tanam antar rumpun bibit $(P<0,05)$. Pertumbuhan mutlak perlakuan bobot bibit awal terbesar pada metode long line dan lepas dasar sama yaitu pada bobot $125 \mathrm{~g}$. Laju pertumbuhan harian perlakuan jarak tanam antar rumpun terbesar pada metode long line dan lepas dasar pun sama yaitu pada jarak $15 \mathrm{~cm}$.Budidaya rumput laut Gelidium menggunakan kantong pada metode long line dan lepas dasar memiliki teknis yang sama baik dari segi bobot awal dan jarak tanam antar rumpun bibit.
\end{abstract}

Kata kunci: Budidaya; Gelidium; kantong; lepas dasar; long line

\begin{abstract}
The purpose of this study was to determine the growth of Gelidium sp. cultivated with pouch on two different methods, namely long lines and bottom-off.The experiment design used was Completely Randomized Design (CRD) which consisted of two methods (long line and bottom-off) and two treatments, namely: 1. Test the initial weight of seaweed (weight of seeds $10 \mathrm{~g}, 20 \mathrm{~g}, 30 \mathrm{~g}, 40 \mathrm{~g}, 50 \mathrm{~g}, 75 \mathrm{~g}, 100 \mathrm{~g}$, and $125 \mathrm{~g}$ ) and 2. Test the spacing between seedlings $(10 \mathrm{~cm}, 15 \mathrm{~cm}, 20 \mathrm{~cm}$ and $25 \mathrm{~cm})$. Each treatment was repeated three times. The results showed that the growth of Gelidium sp. using the long line and bottom-off methods significantly affected the initial weight and spacing between seedlings $(\mathrm{P}<0.05)$. Absolute growth of the initial seedling weight treatment is the largest in the same long line and bottom-off method, which is $125 \mathrm{~g}$. The daily growth rate of the treatment of the spacing between the largest clumps on the long line and bottom-off methods was the same, namely at a distance of $15 \mathrm{~cm}$. Gelidium seaweed cultivation using pouch on the long line and bottom-off methods has the same technical both in terms of initial weight and spacing between seedlings.
\end{abstract}

Keywords: Cultivation; Gelidium; pouch; bottom-off; long line

\section{PENDAHULUAN}

Rumput laut merupakan salah satu komoditas utama perikanan budidaya yang bernilai ekonomis tinggi dengan peluang pasar yang cukup luas. Setiap tahun produksi rumput laut terus mengalami peningkatan dari 2,574 juta ton pada tahun 2009 menjadi 3,028 juta ton pada tahun 2010 sehingga Indonesia menjadi salah satu negara produsen rumput laut terbesar dunia. Rumput laut banyak dimanfaatkan karena mengandung agar, karagenan, porpiran, furcelaran maupun pigmen fikobilin (terdiri dari fikoeritrin dan fikosianin) yang merupakan cadangan makanan yang mengandung banyak karbohidrat (Bunga et al., 2013). Beberapa jenis rumput laut yang tumbuh di Perairan Indonesia dan mempunyai nilai ekonomis antara Iain Kappaphycus, Eucheuma, Glacilaria, Gelidium, Hypnea, dan Sargassum (Basmal et al., 2013).
Rumput laut Gelidium sp. merupakan salah satu jenis rumput laut yang mulai dikembangkan dan mempunyai potensi cukup besar. Potensi rumput laut Indonesia diperkirakan sebesar 480.850 ton/tahun dengan potensi rumput laut Gracilaria sp. sebesar 23.300 ton/tahun dan Gelidium sp. 4.500 ton/tahun. Beberapa jenis rumput laut dari golongan Rhodophyceae (Gracilaria dan Gelidium) biasa dipakai sebagai sumber agar-agar. Kualitas agaragar yang berasal dari Gelidium/Gelidiella lebih tinggi dibanding Gracillaria. Agar berkualitas tinggi dihasilkan dari rumputlaut Gelidium karena tingginya kekuatan gel dan rendahnya kandungan sulfat (Rosulva, 2008). Potensi Gelidium ini hanya berasal dari alam yang belum dikelola secara maksimal. Terbatasnya teknologi budidaya rumput laut Gelidium sp. dengan metode yang tepat menyebabkanbelum optimal produksinya. 
Percobaan budidaya Gelidium telah dilakukan (Muslimin et al., 2018) namun pertumbuhan bobot Gelidium pada semua perlakuan bobot awal dan jaraktanam antar rumpun mengalami penurunan dari bobot awal. Hal ini disebabkan bukan karena bibit mengalami kerusakan/ kematian melainkan disebabkan oleh kondisi morfologi Gelidium yang berukuran relatif kecil per rumpunnya. Ukuran Gelidium yang relatif kecil menyebabkan 1 (satu) titik tali pengikat bibit bukan hanya terdiri dari 1 rumpun Gelidium, tetapi terdiri dari banyak rumpun sehingga jika tergoyang sedikit oleh arus, bibit dengan mudahnya terlepas dari ikatan. Hal ini memunculkan gagasan untuk mengkajipenerapan metode kantong untuk mengurangi risikotersebut. Kajian budidaya rumput laut Gelidium sp.dengan kantong menggunakan metode long line dan lepas dasar akan menambah informasimengenai teknis metode yang tepat dan sesuai untukmengembangkan budidaya rumput laut Gelidium sp. Tujuan penelitian ini adalah untuk mengetahui responspertumbuhan rumput laut Gelidium sp. yangdibudidayakan dengan kantong menggunakan metode long line dan lepas dasar.

\section{BAHAN DAN METODE}

Bahan

Penelitian dilaksanakan pada bulan Agustus-September 2017 di Desa Doda Bahari, Kecamatan Sangia Wambulu, Kabupaten Buton Tengah, Sulawesi Tenggara. Bibit Gelidium sp. diambil dari Pantai Krakal yang terletak di Desa Ngestirejo, KecamatanTanjungsari, Kabupaten Gunung Kidul, Provinsi Daerah Istimewa Yogyakarta (Koordinat GPS: $8^{\circ} 08^{\prime} 50.8^{\prime \prime} \mathrm{S} 110^{\circ} 35^{\prime} 43.3^{\prime \prime} \mathrm{E}$.

\section{Metode}

\section{Persiapan bibit dan rancangan percobaan}

Bibit Gelidium yang didatangkan dari Yogyakarta, diadaptasi terlebih dahulu selama 3 hari di perairan Doda Bahari. Bibit yang akan dibudidaya dibersihkan dari kotorankotoran dan organisme yang menempel pada rumput laut. Setelah adaptasi selesai maka beberapa uji coba dengan metode long line dan lepas dasar dilakukan, yaitu: Uji coba bobot awal menggunakan perlakuan bobot 10, 20, 30, 40 dan 50, 75, 100, dan 125 g/rumpun. Tiap perlakuan diulang sebanyak tiga kali. Unit-unit percobaan disusun dengan Rancangan Acak Lengkap (RAL). Ukuran konstruksi budidaya 24×15 m dengan jarak antar rumpun $15 \mathrm{~cm}$ dan jarak antar tali bentangan $1 \mathrm{~m}$. Penempatan rumput laut perlakuan dalam konstruksi budidaya dilakukan secara acak. Pemeliharaan dilakukan selama 45 hari (1 siklus) dengan melakukan sampling pertumbuhan tiap 15 hari pada rumput laut uji. Rumput laut uji sebanyak 20 rumpun diberi tagging ditiap unit percobaan. Sebagai data dukung, juga dilakukan pengukuran kandungan agar tiap 45 hari dan kualitas perairan secara in situ (suhu, salinitas, $\mathrm{pH}$, kecepatan arus) sertaex situ (nitrat dan fosfat) tiap 15 hari; Uji coba jarak tanam antar rumpun menggunakan perlakuan jarak antar rumpun 10, 15, 20 dan $25 \mathrm{~cm}$. perlakuan diulang sebanyak tiga kali. Unit-unit percobaan disusun dengan Rancangan Acak Lengkap (RAL). Bobot rumpun yang digunakan setiap tali mengacu pada bobot bibit rumput laut Glacilaria yang juga penghasil agar yaitu sekitar 25 g/rumpun. Ukuran konstruksi budidaya 12x15 $\mathrm{m}$ dengan jarak antar tali bentangan $1 \mathrm{~m}$. Penempatan rumput laut perlakuan dalam konstruksi budidaya dilakukan secara acak. Pemeliharaan dilakukan selama 45 hari (1 siklus) dengan melakukan sampling pertumbuhan tiap 15 hari pada rumput laut uji. Rumput laut uji sebanyak 20 rumpun diberi tagging tiap unit percobaan. Sebagai data dukung, juga dilakukan pengukuran kandungan agar tiap 45 hari dan kualitas perairan secara in situ (suhu, salinitas, $\mathrm{pH}$, kecepatan arus) dan ex situ (nitrat dan fosfat) tiap 15 hari.
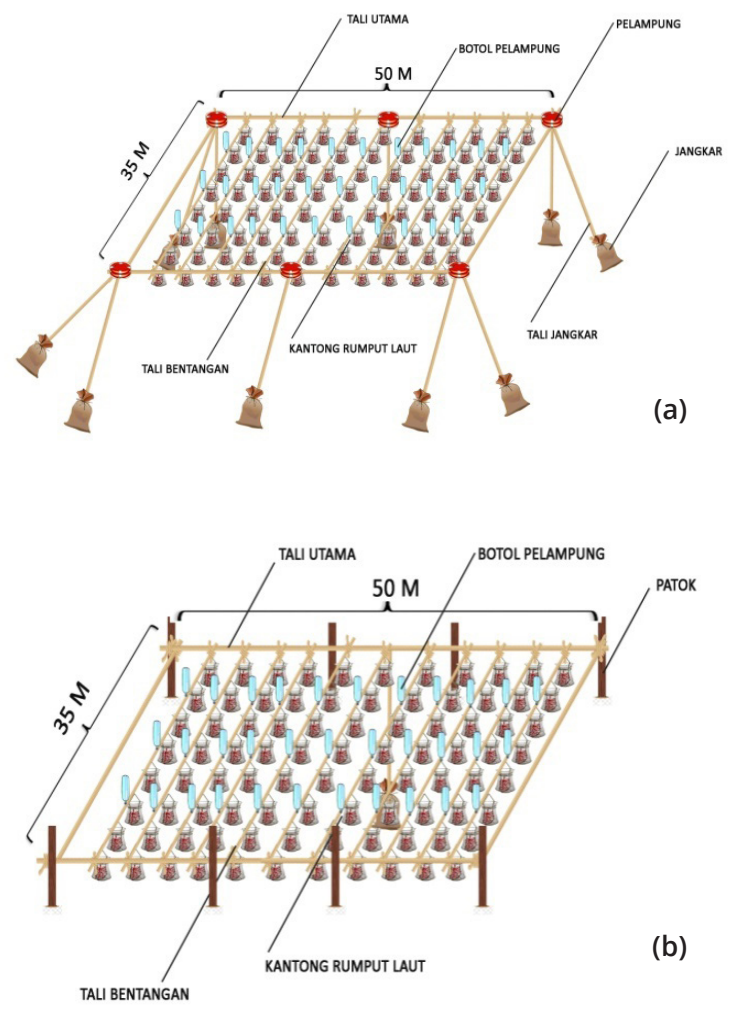

Gambar 1. Desain wadah budidaya rumput laut dengan metode long line (a) dan lepas dasar (b).

\section{Analisis data}

Untuk mengetahui pengaruh setiap perlakuan terhadap variabel yang akan diamati maka dianalisis dengan sidik ragam (ANOVA) yang diolah dengan menggunakan program SPSS (Versi 16.). Jika analisis menunjukkan pengaruh nyata maka dilanjutkan uji Tukey dengan taraf kepercayaan 95\%. Pertumbuhan mutlak dan laju Pertumbuhan Harian (LPH) rumput laut diukur hanya satu kali yaitu pada saat panen (umur 45 hari). Menurut Effendi (1997), pertumbuhan mutlak dihitung dengan menggunakan rumus sebagai berikut :

$$
\begin{aligned}
& \mathrm{G}=\text { Wt-Wo ........................................ } \\
& \text { Keterangan: } \\
& \mathrm{G} \quad=\text { Pertumbuhan mutlak rata-rata }(\mathrm{g}) \\
& \mathrm{Wt} \quad=\text { Bobot bibit pada akhir pada waktu } t(\mathrm{~g}) \\
& \mathrm{Wo} \quad=\text { Bobot bibit pada awalpenelitian }(\mathrm{g})
\end{aligned}
$$

Menurut Hunget al(2009), LPH dapat dihitung dengan menggunakan rumus sebagai berikut: 


$$
\begin{aligned}
& \ln W_{t}-\ln W_{0} \\
& \mathrm{LPH}=\times 100 \% \\
& \mathrm{t}
\end{aligned}
$$

Keterangan :

$$
\begin{aligned}
& \mathrm{LPH}=\text { Laju pertumbuhan harian (\%/hari) } \\
& \mathrm{W}_{t}=\text { Bobot akhir pada waktu } t(\mathrm{~g}) \\
& \mathrm{W}_{o}=\text { Bobot awal }(\mathrm{g}) \\
& \mathrm{t} \quad=\text { Lama pemeliharaan (hari) }
\end{aligned}
$$

\section{HASIL DAN PEMBAHASAN}



Gambar 2. Pertumbuhan mutlak Gelidium sp. dengan bobot awal rumpun berbeda menggunakan metode long line dan lepas dasar.

Semakin besar bobot awal Gelidium, semakin tinggi pula pertumbuhan mutlaknya. Bobot awal $125 \mathrm{~g}$ memiliki pertumbuhan mutlak Gelidium paling tinggi yaitu 109,67 g untuk metode long line dan 131,33 g untuk metode lepas dasar. Bobot awal $10 \mathrm{~g}$ memiliki pertumbuhan mutlak Gelidium paling rendah yaitu $19 \mathrm{~g}$ untuk metode long line dan 9,33 g untuk metode lepas dasar (Gambar 2). Gelidium yang dibudidayakan dengan bobot awal $125 \mathrm{~g}$ memiliki performansi pertumbuhan dan kondisi fisik yang lebih baik bila dibandingkan dengan bobot $10 \mathrm{~g}$. Pada bobot 125 g, Gelidium tampak lebih bersih, cerah, rimbun,dan berwarna segar dibandingkan dengan bobot $10 \mathrm{~g}$. Bobot awal bibit yang digunakan dalam budidaya rumput laut akan memengaruhipertumbuhannya. Penggunaan bobot awal yang cukup akan memberikan respons pertumbuhan yangbaik karena ruang tumbuh yang lebih luas. Bibityang baik berasal dari tanamanyang subur, bersih, dan mempunyai titik tumbuh yang banyak (Sari \& Muslimin, 2016).Jika dikaitkan dengan hasil penelitian ini, rumpun rumput laut Gelidium dengan bobot awalbibit $125 \mathrm{~g}$ memiliki ruang tumbuh yang lebih luas jika dibandingkan dengan perlakuan yang lainnya. Ruang tumbuh yang luas menyebabkan talus rumputlaut tidak saling menutupi sehingga penyerapan cahaya matahari dan zat hara menjadi lebih efektifdan pertumbuhan rumput laut yang lebih optimal.



Gambar 3. Laju pertumbuhan harian Gelidium sp. dengan jarak tanam berbeda antar kantong rumput laut menggunakan metode long line dan lepas dasar.

Pertumbuhan bobot Gelidium berpengaruh nyata terhadap jarak tanam antar kantong rumput laut yang diuji cobakan $(P<0,05)$. Jarak tanam $15 \mathrm{~cm}$ memiliki nilai laju pertumbuhan harian (LPH) Gelidium lebih tinggi bila dibandingkan dengan jarak tanam antar kantong lainnya yaitu 3,69\%/hari untuk metode long line dan 3,27\%/hari untuk metode lepas dasar. Jarak tanam $25 \mathrm{~cm}$ memiliki LPH paling rendah bila dibandingkan dengan jarak tanam antar kantong rumput laut lainnya yaitu 2,13\%/hari untuk metode long line dan 2,24\%/hari untuk metode lepas dasar (Gambar 3).

Tingginya LPH pada perlakuan jarak tanam $15 \mathrm{~cm}$ dikarenakan pada jarak tanam $15 \mathrm{~cm}$ secara nyata mempangaruhi pertumbuhan rumput laut dari aspek suplai nutrisi. Jarak tanam rumput laut dapat mempengaruhi persaingan dalam mendapatkan unsur hara atau nutrien. Unsur hara/nutrien yang diperoleh rumput laut untuk pertumbuhannya seperti belerang, silikon, fospor, kalsium, besi, iodium dan brom. Hal ini didukung oleh pernyataan Darmawati (2015) bahwa pertumbuhan rumput laut dipengaruhi oleh jarak bibit. Jarak tanam mempengaruhi lalu lintas pergerakan air dan akan menghindari terkumpulnya kotoran pada talus yang akan membantu pengudaraan sehingga proses fotosintesis yang diperlukan untuk pertumbuhan rumput laut dapat berlangsung serta mencegah adanya fluktuasi yang besar terhadap salinitas maupun suhu air. Semakin luas jarak tanam maka semakin luas pergerakan air yang membawa unsur hara sehingga pertumbuhan rumput laut dapat meningkat. Pernyataan ini tidak demikian dalam penelitian ini karena selain jarak tanam, faktor yang mempengaruhi pertumbuhan rumput laut adalah kondisi hidrologi perairan seperti suhu, salinitas, arus, $\mathrm{pH}$, dan nutrien serta kompetitor rumput laut itu sendiri. 
Kandungan agar

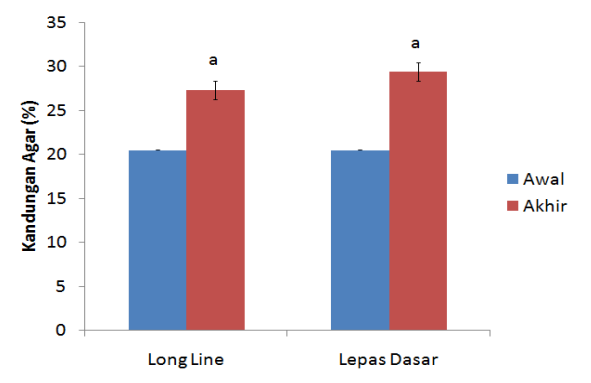

Gambar 4. Kandungan agar Gelidium sp.yang dibudidayakan dengan metode berbeda.

Kandungn agar Gelidium tertinggi pada metode lepas dasar dan terendah pada metode long line namun tidak berpengaruh nyata( $P>0,05)$ (Gambar 4). Hal ini disebabkan karena kandungan agar pada rumput laut tidak dipengaruhi oleh metode budidaya yang digunakan namun lebih dipengruhi oleh jenis rumput laut, lokasi budidaya, dan metode ekstraksi. Menurut Yunizal (2002), kandungan agar-agar dalam talus Gelidum sangat bervariasi menurut jenis dan lokasi tumbuh. Kandungan agarnya berkisar antara $12-48 \%$.

Gelidium pussilum yang tumbuh di perairan Veraval, India mempunyai kandungan agar 22\%. Selanjutnya, kandungan agar pada G. pristoides yang tumbuh di Port Alferd, Afrika Selatan adalah sebesar 30-48\% berat kering. Gelidium latifolium yang tumbuh di Roscoff (sebelah utara Britain), memiliki kandungan agar 26-42\% kering. Sementara itu Gelidium yang tumbuh di perairan Sulawesi mempunyai kandungan agar mencapai 30\% (Sjafrie, 1999).

\section{Kualitas perairan}

Parameter kualitas air yang diamati dalam penelitian ini berupa suhu air $\left({ }^{\circ} \mathrm{C}\right)$, salinitas (ppt), $\mathrm{pH}$, kecepatan arus $(\mathrm{m} / \mathrm{s})$, nitrat (mg/L), fosfat (mg/L), bahan organik total (BOT) (mg/L), dan TSS (mg/L), (Tabel 1). Parameter fisik perairan (suhu air, salinitas, pH, keepatan arus) diukur langsung saat pengamatan, sedangkan parameter nitrat, fosfat, BOT, dan TSS melalui analisa laboratorium di Fakultas Perikanan Universitas Hasanuddin, Makassar.

Tabel 1. Nilai parameter kualitasperairan di lokasipengamatan.

\begin{tabular}{lllll}
\hline \hline No & Parameter & Satuan & $\begin{array}{l}\text { KisaranNilai } \\
\text { Long Line }\end{array}$ & Lepas Dasar \\
\hline 1. & Suhu & ${ }^{\circ} \mathrm{C}$ & $28,1-28,3$ & $27,5-28,2$ \\
2. & Salinitas & $\mathrm{ppt}$ & $31-34$ & $30-33$ \\
3. & $\mathrm{pH}$ & & $8-8,2$ & $8-8,2$ \\
4. & Kec. arus & $\mathrm{m} / \mathrm{s}$ & $0,61-0,90$ & $0,54-0,82$ \\
5. & Nitrat & $\mathrm{mg} / \mathrm{L}$ & $0,85-1,33$ & $0,75-0,91$ \\
6. & Fosfat & $\mathrm{mg} / \mathrm{L}$ & $0,43-0,44$ & $0,43-0,49$ \\
\hline
\end{tabular}

Hasil pengukuran parameter fisik dan kimia lingkungan perairan (suhu air, salinitas, $\mathrm{pH}$, kecepatan arus, nitrat, dan fosfat) menunjukkan bahwa kondisi hidrologi pada lokasi budidaya dengan menggunakan metode long line dan lepas dasar masih dalam kategori yang baik untuk menunjang kehidupan rumput laut. Kondisi hidrologi pada lokasi budidaya dengan menggunakan metode long line dan lepas dasar memiliki perbedaan yang tidak begitu signifikan karena terletak di daerah selat yang memiliki sirkulasi/pergerakan air cukup bagus dan merata sehingga stratifikasi parameter fisik dan kimia perairan tersebut tidak begitu tinggi.

Setiap makhluk hidup memiliki toleransi yang berbeda terhadap suhu. Umumnya suhu akan berpengaruh terhadap proses-proses metabolisma tubuh. Hasil pengukuran suhu perairan selama pemeliharaan Gelidium sp. berkisar antara $28,1-28,0^{\circ} \mathrm{C}$ (lokasi metode long line) dan $27,5-28,2^{\circ} \mathrm{C}$ (lokasi metode lepas dasar).Pada Gelidium, faktor suhu akan berpengaruh terhadap sebaran vertikal dari rumput laut ini. G. cartilageneum dan G. nudiform yang hidup pada kedalaman 13-14 meter dapat bertahan hidup pada suhu di bawah $30-32^{\circ} \mathrm{C}$, sedangkan G. pussilum yang hidup di daerah upper intertidal tumbuh baik (optimal) pada suhu $20^{\circ} \mathrm{C}$. Selanjutnya G. rex yang hidup di daerah sub tidal tumbuh optimal pada suhu $15^{\circ} \mathrm{C}$ (Santelices, 1988). Menurut Hariyati (2008) alga merah jumlahspora optimum terlepas terjadi padatemperatur $\pm 30^{\circ} \mathrm{C}$. Sedangkan kondisi dialam temperatur berkisar antara $27-33^{\circ} \mathrm{C}$.

Kemampuan adaptasi Gelidium terhadap salinitas cukup bervariasi, tergantung dari masing-masing jenis. Misalnya G. pussilum memiliki kisaran salinitas antara 26,3 - 31.36 permil. G. corneum dari Texas, dapat hidup pada salinitas minimum 13 permil dan salinitas maksimum 37 permil (Santelices, 1988). Hasil pengukuran salinitas selama pemeliharaan Gelidium sp. berkisar antara 31-34 ppt (lokasi metode long line) dan 30-33 ppt (lokasi metode lepas dasar). Di Indonesia Gelidium cenderung hidup di daerah yang bersalinitas tinggi, misalnya di Bali 33 permil, di Cilurah Banten 34 permil dan di Seram Timur 34 permil (Atmadja \& Sulistijo, 1988) dan belum pernah ada publikasi yang menyatakan bahwa ada Gelidium yang hidup pada salinitas rendah (Sjafrie, 1999).

Nilai pH selama penelitian tergolong dalam besaran optimal untuk pertumbuhan Gelidium sp.

Menurut Hariyati (2008) perubahan pH terjadi karena oksigen terlarut tinggi (suhu meningkat) sehingga $\mathrm{CO}_{2}$ bebas akan menurun. Hal ini akan mengakibatkan keseimbangan karbonat mengarah ke kanan sehingga ion $\mathrm{H}+$ banyak digunakan dan $\mathrm{pH}$ air naik.

Kecepatan arus yang terukur di lokasi berkisar antara 0,61-0,90 m/s (lokasi metode long line)dan 0,54-0,82 (lokasi metode lepas dasar). Kecepatan arus ini sesuai dengan kondisi habitat alami Gelidium yang berkisar antara 0,60-0,83 m/s. Umumnya Gelidium tumbuh di daerah yang berombak besar, dimana pergerakan air (ombak) dan arus yang relatif besar (Atmadja\& Sulistijo, 1988). Satelices (1988) mengatakan bahwa suku Gelidiaceae digolongkan kedalaman rumput laut yang dapat hidup pada pergerakan air sedang sampai keras.

Nitrat dan fosfat memainkan peran penting dalam pertumbuhan alga termasuk rumput laut sedangkan nitrogen adalah faktor pembatas utama nutrien untuk pertumbuhan alga pada ekosistem laut. Keberhasilan budidaya rumput laut membutuhkan pengetahuan tentang kebutuhan nitrogen untuk alga. Martins et al. (2011) melaporkan bahwa kekurangan nutrien pada beberapa spesies alga dapat berdampak pada penurunan pertumbuhan akibat perubahan formasi dan penurunan 
kandungan protein dan phycobiliprotein terlarut. Kadar unsur nitrat dan fosfat yang diperoleh pada saat penelitian berkisar antara 0,85-1,33 mg/L dan 0,43-0,44 mg/L (lokasi metode long line) dan 0,75-0,91 mg/L dan 0,430,49 mg/L (lokasi metode lepas dasar). Mala et al.(2016) menyatakanbahwa nitrat dan fosfat yang baik bagi rumputlaut adalah kisaran 0,9-3,5 ppm dan 0,1-3,5 mg/L.

\section{KESIMPULAN DAN SARAN}

\section{Kesimpulan}

Budidaya rumput laut Gelidium sp.menggunakan kantong yang ditanam pada metode long line dan lepas dasar dengan bobot awal $125 \mathrm{~g}$ dan jarak tanam $15 \mathrm{~cm}$ menghasilkan pertumbuhan yang lebih baik.

\section{Saran}

Budidaya rumput laut Gelidium dengan menggunakan kantong harus diberikan pemeliharaan dan pembersihan yang rutin agar tetap bersih sehingga tidak mengganggu pertumbuhan rumput laut di dalamnya.

\section{UCAPAN TERIMAKASIH}

Penulis mengucapkan terima kasih kepada teknisi yang terlibat dalam kegiatan ini (Ilham, Twynnugroho Hadi Wiyanto, dan Handy Burase) dan Bapak Sahirudin selaku pembudidaya rumput laut Desa Doda Bahari. Penelitian ini dibiayai dari dana DIPA APBN KKP tahun 2017.

\section{DAFTAR PUSTAKA}

Atmadja, W.S. \& Sulistijo. 1988. Sebaran dan habitat Gelidium di Indo-nesia. Penelitian Oseanologi Perairan Indonesia Buku I: Biologi, Geologi, Lingkungan dan Oseanografi: 69-73

Bunga, S.M., R.I. Montolalu, J.W. Harikedua, L.A.D.Y. Montolalu, A.H. Watung N. Taher. 2013. Karakteristik sifat fisika kimia karaginan rumput laut Kappaphycus alvarezii pada berbagai umur panen yang diambil dari daerah Perairan Desa Arakan Kabupaten Minahasa Selatan. Jurnal Media Teknologi Hasil Perikanan.1 (2): 54-58

Darmawati. 2015. Optimasi jarak tanam bibit terhadap pertumbuhan Caulerpa spdi Perairan Laguruda Kabupaten Takalar. Jurnal IImu Perikanan Octopus. 4 (1): 337-44

Effendi, I. 1997. Analisis data pertumbuhan rumput laut. Jurusan Manajemen Sumberdaya Perairan Fakultas Perikanan dan IImu Kelautan. IPB. Bogor. 76 pp
Hariyati, R. 2008. Optimalisasi faktor lingkungan terhadap jumlah spora terlepas pada Gelidium sp. Buletin Anatomi dan Fisiologi. 16 (2): 46-53

Hung, L.D., K. Hori, H.Q. Nang, T. L.T. Hoa. 2009. Seasonal changes in growth rate, carrageenan yield and lectin content in the red alga Kappaphycus alvarezii cultivated in Camranh Bay, Vietnam.Journal of Applied Phycology. 21: 265-72

Mala, L., G. Latama, Abustang A. Tuwo. 2016. Analisis perbandingan pertumbuhan rumput laut Kappaphycus alvarezii varietas coklat yang terkena epifit di Perairan Libukang, Kabupaten Jeneponto. Jurnal Rumput Laut Indonesia. 1 (1): 52-56

Martins, A.P., O.N. Junior, P. Colepicolo N.S. Yokoya. 2011. Effects of nitrate and phosphate availabilities on growth, photosynthesis and pigment and protein contents in colour strains of Hypneamusciformis (Wulfen in Jacqu.) J.V. Lamour. (Gigartinales, Rhodophyta). Rev. Bras. Farmacogn. 21(2) : 1-18

Muslimin, S., N.H. Sarira P.R. Pong-Masak. 2018. Pengaruh bobot bibitdan jarak tanam terhadap pertumbuhan rumput laut Gelidium corneum. Prosiding SemnaskanUGM Seminar Nasional Tahunan XV Hasil Penelitian Perikanan dan Kelautan Jilid I Budidaya Perikanan. 45-52

Rosulva, I. 2008. Pembuatan agr bakto dari rumput laut Gelidium sp. dengan khitosan sebagai absorben. Skripsi. Program Studi Teknologi Hasil Perikanan. Fakultas Perikanan dan IImu Kelautan. IPB. Bogor. 42 $\mathrm{pp}$

Santelices, B. 1988. Synopsis of biologi-cal data on seaweed genera Gelidium and Pterocladia (Rhodophyta). FAO Fish. Synop.(145): 55

Sari, W.K.P. Muslimin. 2016. Penentuan bobot bibit, jarak rumpun, dan jarak tali bentangan untuk optimalisasi budidaya rumput laut Sargassum duplicatum dengan metode lepas dasar di Perairan Mananggu Kabupaten Boalemo, Gorontalo. Prosiding Forum Inovasi Teknologi Akuakultur 25-26 April 2016 Surabaya, Indonesia. FITA: 509-517.

Sjafrie, N.D.M. 1999. Beberapa catatan tentang Gelidium (Rhodophyta). Oseana. 24 (3) 1-10

Yunizal. 2002. Teknologi ekstraksi agar-agar dari rumput laut merah (Rhodophyceae). Pusat Riset Pengolahan Produk dan Sosial EkonomiKelautan dan Perikanan. Pusat Riset Kelautan dan Perikanan. DepartemenKelautan dan Perikanan. Jakarta. 